\title{
Identification and Prioritization of Critical Success Factors in Implementation of Knowledge Management Case study: Power Distribution Company of Kurdistan Province
}

\author{
${ }^{1}$ Ruhollah Tavallaei \\ ${ }^{2}$ Rozbeh Fadaei
}

\author{
${ }^{1}$ Faculty member of Shahid Beheshti University. Email: tavallaee.r@gmail.com \\ ${ }^{2} P h D$ Student of Technology Management, Hamedan Branch, Islamic Azad University, Hamedan, Iran \\ *Corresponding author's E-mail: rozbeh_fadaei@yahoo.com
}

Doi:10.5901/mjss.2016.v7n5s1p135

\begin{abstract}
In information community, knowledge is one of the most important resources of organization. To achieve competitive advantage, the organizations should manage their knowledge assets and capital accurately. Knowledge management systems can manage the organizational knowledge. However, implementation of these systems is encountered with some challenges leading to the failure of implementation of knowledge management system. By recognition of Critical success factors in implementation of knowledge management, the risk of implementation of knowledge management system is reduced. The present study is aimed to identify and classify the effective factors on implementation of knowledge management in power distribution company of Kurdistan province. After the evaluation of review of literature, these factors are identified and initial model is extracted. The applied research approach and its method is descriptive-survey. The study population is employees of power Distribution Company of Kurdistan province as 252. To evaluate the study variables, questionnaire is applied. The reliability of study measures is evaluated using Cronbach's alpha and validity is evaluated using the opinion of experts. The results showed that effective factors on implementation of knowledge management in power Distribution Company of Kurdistan province were not effective equally and the main factor in implementation of knowledge management is "IT infrastructure".
\end{abstract}

Keywords: Critical success factors, Knowledge, Knowledge management implementation, Power Distribution Company

\section{Introduction}

Increasing recognition in global business considers knowledge as important resources and knowledge resources are of great importance compared to common resources as land and capital (Wu and Wang, 2006). The basis of organizational competition in present economy is changed from physical resources to knowledge. The main focus of information systems from information management is changed to knowledge management. The businesses achieving included knowledge in organizations and can develop it to operation, productions and services, have more advantages compared to competitors. Most of organizations increasingly are considered as knowledge-based companies in which knowledge management is necessary. Knowledge management is turned into true business activity for organizations as they know competition is the main factor of knowledge management (Grover and Davenport, 2001).

The nature of knowledge is described as "true balanced belief" (Nonaka and Takeuchi, 2001). Bell considers knowledge as a mental feature associated to a name or group of names and is supported by publish or some other forms of recognition (e.g. publications) (Alvesson and Karreman ,2001). Davenport and Prusak defines knowledge as a fluid flow of experience, value, environmental information and expert attitude providing a framework for evaluation and collaboration of new information and experiences (Davenport and Prusak,1998). In recent years, knowledge management is one of the most important activities for successful business. By emergence of global pressure, the companies can not ignore learning capacity. The failure in work leads to bad performance and probable forgetting (Alazmi and Zairi,2003). Knowledge management is a field improving an integrated approach to determine, take, evaluate and exchange the information assets of company. These assets include data basis, documents, policy, procedures and previous expert and work experience of people (Srikantaih and Koeing,2001). Goodman and Chinowsky believed that decision makers should consider knowledge management as they are important for organizational survival and competition (Kayani and Zia, 2012). Okunoye and Karsten (2002) believed that knowledge management was the main source of success for organizations without the size and geographical situation of organizations. Thus, better understanding of Critical Success Factor is required to guaranty the success of efforts (Wong, 2005). 
By increase of inclination of organizations to use knowledge management system, perception of significance and success in this regard is of great importance for authorities of implementation of knowledge management system in organizations to know the effective factors on implementation of knowledge management system and consider their relationship and determine the strengths and weaknesses of organization and have better planning and high effectiveness and implement knowledge management (Rezayinur et al., 2014). Determine Critical success factors can help planning and implementation of knowledge management to reduce failure risk. The main duty of Critical success factors is knowledge management, determination and supervision of these factors for successful implementation of knowledge management. Thus, any activity in implementation of knowledge management by organization should be considered before (Ranjan and Bhatnager,2008).

The present study attempts to evaluate the review of literature and identify Critical success factors in implementation of knowledge management, then a conceptual model for power distribution company of Kurdistan province is proposed and significance of each of Critical factors in conceptual model is defined.

\section{Review of Literature}

\subsection{Knowledge}

Knowledge is defined as awareness, understanding or familiarity via study, evaluation, observation or experience during specific period (Bolinger and Smith, 2001). According to Gammelgaard and Ritter, knowledge is a combination of experiences, value, environmental information and expert attitude providing a framework for evaluation and collaboration of experiences and new information. Knowledge is organized in the mind of experts. In organizations, knowledge is not only placed in documents but also in norms, operation, routine organizational processes (Al-Alawi et al, 2007). Knowledge should not be mistaken for data. Data are facts, measurements and raw data. Knowledge is much complex than information. Information is achieved of organized data as significant forms. Knowledge is the result of information interpretation based on one's understanding and is affected by people personality as it is dependent upon judgment and perception, knowledge combines beliefs, attitude and behavior together (Lee and Yang, 2000). Knowledge is the most useful form of satisfaction for problem solving and decision making as knowledge has meaning higher than data and information. Data refers to raw facts without any processing or analysis. Information refers to the data as processed and gives much meaning to users. Thus, knowledge is more than data and information combining it with information and experiences to show the applied methods and procedures by others and can be used in future to solve similar issues (Hesham and Min, 2008). Knowledge can be perceived as tacit and explicit knowledge. Polanyi distinguishes between tacit and explicit knowledge. Explicit knowledge is available normally and is documented well (Polanyi, 1958). Showing the difference between two types of knowledge, Polanyi states that we know more than we say (Polanyi, 1966). Nonaka et al., expressed explicit knowledge as formal and systematic form and shared as data and formulas. Tacit knowledge is attitude, feelings as individual placed in this level of knowledge (Hislop, 1966). Mir states that tacit knowledge is competitive as determination, increase and its exchange are difficult (Kayani and Zia, 2012).

\subsection{Knowledge management}

Knowledge management suffers from "Three blind and one elephant" (Dalkir, 1962). We refer to different definitions of knowledge management in this section:

- Knowledge management includes using intellectual assets with the aim of improving organization performance (Stankosky,2008)

- Swan et al defined knowledge management " widely" as any process, operation dealing with creation, acquisition, storage, exchange and using knowledge, skills and specialization (Alvesson and Karreman,2001).

- Knowledge management is knowledge management of the company improving a series of performance features of organization via "Intelligent Acting"( Wiig,1993).

- Knowledge management is the process of creation, credit, presentation, distribution and application of knowledge (Bhatt, 2001).

- Knowledge management means knowledge management of company and organization via special organizational process for acquisition, organizing, retention, application, exchange and review of tacit and explicit knowledge of staffs to increase organizational performance and value creation (Alavi and Linder, 2001). 
- Knowledge management is acquiring true information for apocopate people at appropriate time, helping people in knowledge creation and exchange and working on information (Holm, 2001).

\subsection{Implementation of knowledge management: Critical success factors}

Oakland defined Critical success factors as what companies perform to achieve goal via evaluation and classification of effects. He states that they are the lowest factors or sub-goals of organization by which they can fulfill the organization mission (Oakland, 1995). These factors play an important role in taking benefits of latent benefits. Achieving them is difficult. These factors are called Critical success factors. The lack of these factors is serious organizational barrier to achieve organizational goals (Karami et al, 2015). Understanding Critical success factors plays important role in successful planning of knowledge management and dissemination of results. Some factors are presented in implementation of knowledge management by scientists and experts (Wu, 2011). For example, Liebowitz proposed six Critical factors for successful implementation of knowledge management in organizations for success in implementation of knowledge management. The need of knowledge management strategy is done with the support of top managers, top employees of knowledge and infrastructure of knowledge management, resources and ontology of knowledge, tools and knowledge management systems as encouraging knowledge exchange and supportive culture (Wong, 2005). According to Hasanali , five effective factors in implementation of knowledge management are leadership, culture, structure, role, responsibilities, infrastructure of IT and measurement (Hasanali,2002). Chourides and Longbottom identified various Critical factors for successful implementation of knowledge management in duty fields and strategy, human resources management, IT, marketing and quality were Critical factors (Motlabi et al., 2013). Based on the studies by various researchers regarding effective factors on knowledge management, we can summarize Critical success factors of knowledge management system as shown in Table 1.

Table 1. Important factors in successful implementation of knowledge management

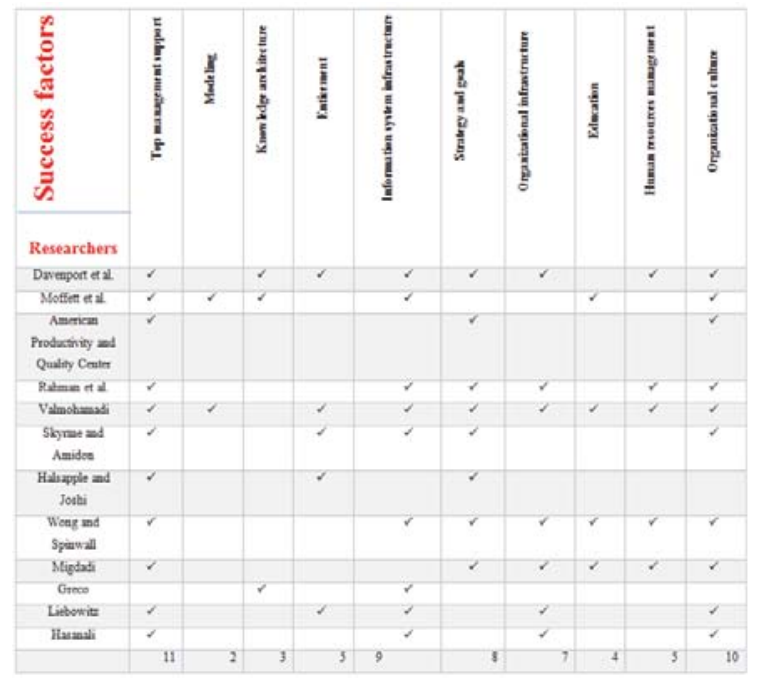

\section{Model and Study Questions}

Based on review of literature, Critical success factors are defined in knowledge management in accordance to the researchers. According to the literature, 6 effective factors on implementation of knowledge management from the view of theorists are supporting top managers, goals and strategy, organizational culture, IT infrastructure, organizational infrastructure, organizational culture. Based on these 6 factors, the initial model for power distribution company of Kurdistan province is shown in Figure 1. 


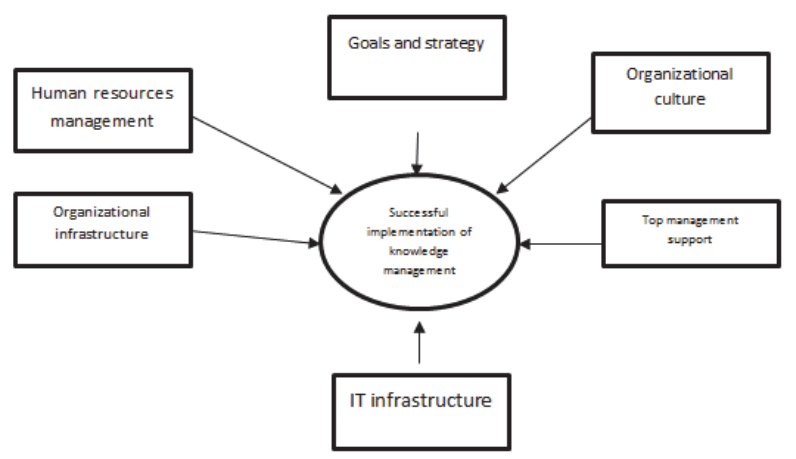

Figure 1- Initial model of study

The above model is based on review of literature, managers of power Distribution Company of Kurdistan province and academic expert opinion in knowledge management. The proposed model has 6 variables and 24 indices. The indices of each variable are shown in Table 2.

Table 2 - The indices of study variables

\begin{tabular}{|c|c|}
\hline Indices of each variable & $\begin{array}{l}\text { Effective variables on } \\
\text { knowledge management } \\
\text { implementation }\end{array}$ \\
\hline $\begin{array}{l}\text { - Opinion of employees about organization policy } \\
\text { - Creativity and innovation as value } \\
\text { - Inclination to continuous leaming } \\
\text { - Inclination of employees to information and knowledge exchange } \\
\text { - Risk taking and mistake as leaming opportunities }\end{array}$ & Organizational culture \\
\hline $\begin{array}{l}\text { - Support of knowledge management projects by managers } \\
\text { - Encouraging employees to creativity and innovation } \\
\text { - Encouraging managers to creation, share and knowledge application }\end{array}$ & Top management support \\
\hline $\begin{array}{l}\text { - Development of knowledge management strategy } \\
\text { - Consistency of knowledge management strategy with business } \\
\text { strategy } \\
\text { - Empowerment of employees }\end{array}$ & Goals and strategy \\
\hline $\begin{array}{l}\text { - Access of enployees to researches performed by employes of organization } \\
\text { - Absorbing people based on knowledge competence } \\
\text { - Providing progress opportunity for employees } \\
\text { - The process of familiarity of new employees with knowledge } \\
\text { management system and its advantages }\end{array}$ & Human resources \\
\hline $\begin{array}{l}\text { - Support of organization structure of team works } \\
\text { - Determine a knowledge leader } \\
\text { - Support of knowledge exchange processes } \\
\text { - Determine roles and responsibilities to perform duties of knowledge management }\end{array}$ & Organizational infrastructure \\
\hline $\begin{array}{l}\text { - User-friendly computer program } \\
\text { - Suitable hardware and software infrastructure of organization } \\
\text { - Access to intemet and intranet of organization } \\
\text { - Update information in website and intranet of organization }\end{array}$ & IT infrastructure \\
\hline
\end{tabular}

This paper responds to two questions as:

1- Which conceptual model can be proposed for Critical success factors in implementation of knowledge management in power Distribution Company of Kurdistan province?

2- In the proposed conceptual model, which factors are of great importance?

\section{Study Methodology}

This study is applied in terms of purpose and descriptive-survey in terms of method and for data collection, a questionnaire (based on Likert scale) is used. The study population is managers and employees of power distribution company of Kurdistan province and study sample is 252. By simple random sampling method, 182 questionnaires are distributed, of which the response of 146 people were given to the researcher (the rate of responding distributed 
questionnaires was $72 \%$ ). Based on the model and lack of a questionnaire to evaluate study model, a questionnaire with 5 demographic questions, 24 questions (5-choice) are designed based on Likert scale. To determine validity of questionnaire, the opinion of expert is used and by Cronbach's alpha, reliability is evaluated and it is achieved by SPSS software as $95 \%$.

\section{Study Results}

To evaluate similarity of ranking (prioritization) of the effect of each of factors on "successful implementation of knowledge management" in the proposed conceptual model, Friedman test is used. Thus, $\mathrm{HO}, \mathrm{H} 1$ are defined as:

$\mathrm{H} 0$ : The priority of the effect of effective factors on implementation of knowledge management success in power Distribution Company of Kurdistan province is similar.

$\mathrm{H} 1$ : The priority of the effect of effective factors on implementation of knowledge management success in power Distribution Company of Kurdistan province is different.

As significance level of test is 0.000 , this value is less than 0.05 and $\mathrm{HO}$ is rejected. The results of prioritization of the effect of model factors on success of knowledge management are shown in Table 3.

Table 3 - Ranking the main factors of study model based on the effect on "successful implementation of knowledge management"

\begin{tabular}{|c|l|c|}
\hline The mean of factor effect & The effect of factor on model & Factor rank \\
\hline 4.42 & IT infrastructure & $\mathbf{1}$ \\
\hline 3.76 & Strategy and goal & $\mathbf{2}$ \\
\hline 3.57 & Top management support & $\mathbf{3}$ \\
\hline 3.32 & Culture & $\mathbf{4}$ \\
\hline 3.28 & Organizational infrastructure & $\mathbf{5}$ \\
\hline 2.65 & Human resources management & $\mathbf{6}$ \\
\hline
\end{tabular}

To evaluate the effect of indices on main factors in study model and prioritization of the effect of each of mentioned indices on main factors, Friedman test for factors is used. The results of SPSS software are shown briefly in Table 4. $\mathrm{H} 0, \mathrm{H} 1$ for prioritization of the effect of each of sub-indices on main factor based on Friedman test are as follows: $\mathrm{HO}$ : The priority of the effect of sub-indices on main factor is similar. $\mathrm{H1}$ : The priority of the effect of sub-indices on main factor is different.

Table 4 - The results of prioritization of identified sub-indices in the study model

\begin{tabular}{|c|c|c|}
\hline Mean of each index (Friedman test) & The priority of the effect of each sub-index on the main factor & Main factor \\
\hline 3.75 & User-friendly computer programs & \multirow{5}{*}{ IT infrastructure } \\
\hline 3.01 & Suitable hardware and software infrastructure of organization & \\
\hline 2.89 & Having access to internet and intranet of organization & \\
\hline 2.60 & Updating information in website and intranet & \\
\hline 2.75 & Consistency of IT and knowledge management & \\
\hline 2.09 & Development of knowledge management strategy & \multirow{3}{*}{ Strategy and goals } \\
\hline 2.06 & Consistency of knowledge management strategy with business strategy & \\
\hline 1.84 & Empowerment of employees & \\
\hline 1.56 & Support of knowledge management projects by managers & \multirow{3}{*}{ Top managers support } \\
\hline 1.44 & Encouraging employees to creativity and innovation & \\
\hline 1.30 & Encouraging managers to creation, sharing and application of knowledge & \\
\hline 3.05 & Opinion of employees about policy of organization & \multirow{5}{*}{ Organizational culture } \\
\hline 2.99 & Creativity and innovation as value & \\
\hline 3.30 & Tendency to continuous learning & \\
\hline 2.89 & Tendency of employees to information and knowledge exchange & \\
\hline 2.78 & Risk taking and mistake are learning opportunities & \\
\hline 2.51 & Support of organization structure of team work & \multirow{4}{*}{ Organizational infrastructure } \\
\hline 2.31 & Determine a knowledge leader & \\
\hline 2.57 & Support of knowledge exchange processes & \\
\hline 2.60 & $\begin{array}{l}\text { Define the roles and responsibilities to perform duties of knowledge } \\
\text { management }\end{array}$ & \\
\hline 2.06 & Access of employees to researches by employees of organization & \\
\hline
\end{tabular}




\begin{tabular}{|l|l|l|}
\hline 2.69 & Absorbing people based on knowledge competence & \multirow{2}{*}{$\begin{array}{c}\text { Human resources } \\
\text { management }\end{array}$} \\
\hline 2.70 & Providing progress opportunity for employees & \\
\hline 2.55 & $\begin{array}{l}\text { Familiarity process of new employees with knowledge management and } \\
\text { its benefits }\end{array}$ & \\
\hline
\end{tabular}

In the next stage, to evaluate correlation in the initial model of study, Spearman correlation coefficient is used. The results of correlation of mentioned factors on IT infrastructure based on SPSS software output are shown in Table 5.

Table 5 - The results of correlation analysis of main factors

\begin{tabular}{|c|c|c|c|c|c|}
\hline $\begin{array}{c}\text { Human resources } \\
\text { management }\end{array}$ & $\begin{array}{c}\text { Organizational } \\
\text { infrastructure }\end{array}$ & $\begin{array}{c}\text { Organizational } \\
\text { culture }\end{array}$ & $\begin{array}{c}\text { Support of top } \\
\text { managers }\end{array}$ & $\begin{array}{c}\text { Strategy and } \\
\text { goal }\end{array}$ & Factor \\
\hline $.583^{* *}$ & $.632^{* *}$ & $.676^{* *}$ & $.583^{\text {t* }}$ & $.610^{* *}$ & IT infrastructure \\
\hline
\end{tabular}

\section{Discussion of Study Results}

The results of answering the demographic questions of 146 questionnaires showed that : $18.3 \%$ (27) respondents were women, $81.7 \%$ (119) men. In terms of age, respondents are 66 ranging 25-35 years, 58 people ranging 35-45 years. In terms of education, 35 diploma, 95 BA, 16 MA. Work experience of 18 people as 1-5 year, 54 people as 5-10 years, 40 people as 10-15 years, 24 people as $15-20$ years, 5 people as $20-25$ years and 5 people above 25 years. In terms of position, there were 19 managers, 127 employees of power Distribution Company of Kurdistan province.

Based on the results of Table 3 achieved by Friedman test, the most important factor in successful implementation of knowledge management in power Distribution Company of Kurdistan province is "IT infrastructure, goals and strategy, top manager support, culture, organizational infrastructure, human resources management. As shown in Table 3, in implementation of knowledge management in power Distribution Company of Kurdistan province, there is instrumental view to knowledge management and culture and management of human resources are less considered.

As shown in Table 5, we can say there is a positive and significant correlation between other main factors on success of knowledge management in power distribution company of Kurdistan province with IT infrastructure.

As shown in the results of Tables 3, 5, the final conceptual model is shown in Figure 2.

Figure 2 - Final model of study

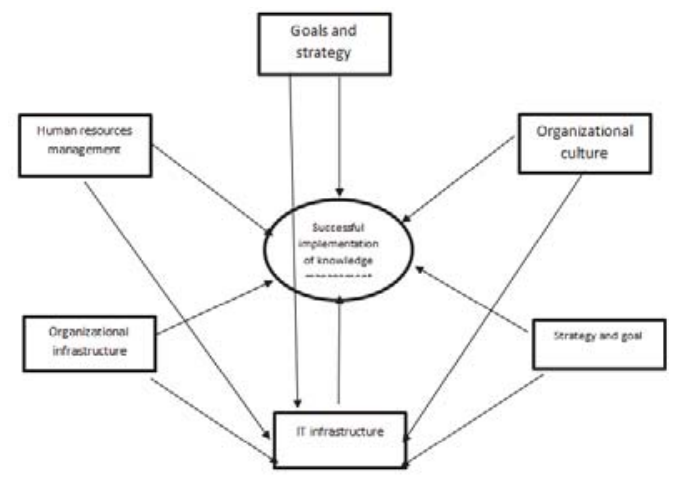

\section{Conclusion}

This study aimed to identify the effective factors on success of implementation of knowledge management in power distribution company of Kurdistan province. By review of literature and identification of effective factors on implementation of knowledge management, the most important factors are considered and other factors are excluded. Then, a questionnaire is raised based on the identified factors.

The results of questionnaire showed that IT infrastructure had great importance in power distribution company of Kurdistan province in implementation of knowledge management and the organization has given much attention to this successful factor compared to other factors. The view of organization managers to knowledge management is hardware 
view and other effective factors namely organizational culture is less considered. The order of Critical success factors for power Distribution Company of Kurdistan province is determined as follows:

1- IT infrastructure

2- Strategy and goals

3- Support of top managers

4- Organizational culture

5- Organizational infrastructure

6- Human resources management

For each of effective factors, effective sub-indices are identified and prioritized and the results are shown in Table 4. The results of correlation analysis in Table 5 showed that "IT infrastructure" was the main factor among the investigated factors in power distribution company of Kurdistan province and all factors had strong and positive correlation with "IT infrastructure".

\section{References}

Donald Hislop, Monavarian, Asgari. 2014. Knowledge management in organization with social-cultural approach

Rezayinur, Shahhosseini, KHosravi. 2014. Presenting a conceptual model based on effective factors on implementation of knowledge management system in co-workers company. Management and technology development. First year. No.4.

Kims Dalkir, Zargarpour, Parimani, Zarabadipour (Translators). 2013. Knowledge management in theory and practice.

Matlabi, Abotaleb; Alipour, Alireza, Nasri, Faramarz. 2013. Identification of effective factors on implementation of knowledge management in higher education and their ranking by Fuzzy Topsis. Scientific-research journal of educational management researches.

Alazmi, M. and Zairi, M. (2003), Knowledge management critical success factors, Total Quality Management, Vol.14,NO.2

Al-Alawi, A I. Al-Marzooqi, N Y. Fraidoon Mohamad, Y. (2007), "Organizational culture and knowledge sharing: critical success factors". Journal Of Knowledge Management, Vol.11 No. 2, pp.22-42.

Alavi, M. and Leidner, D.E. (2001), "Review: knowledge management and knowledge.

Alvesson M, Karreman D, University L.Odd Couple:Making sense of the curious concept of knowledge management . Journal of Management studies 38:7 November 2001.

Bhatt, G. (2001), "Knowledge management in organizations: examining the interaction between technologies, techniques, and people", Journal of Knowledge Management, Vol. 5 No. 1, pp. 68-75.

Bollinger AS, Smith RD. Managing organizational knowledge as a strategic asset. Journal of Knowledge Management 2001;5(1):1-8.

Davenport, T. H. and Prusak, L. (1998), Working Knowledge: How Organizations Manage What They Know, Harvard Business School Press, Boston, Massachusetts.

Grover, V. and Davenport, T.H. (2001), "General perspectives on knowledge management: fostering a research agenda", Journal of Management Information Systems, Vol. 18 No. 1, pp. 5-21.

Hasanali, F. (2002), "Critical success factors of knowledge management", available at: www.Kmadvantage.com/docs/km_articles/ Critical_Success_Factors_of_KM.pdf (accessed 20November 2003).

Heshami. Min, A. (2008)." "Knowledge management implementation in construction projects: a KM model for knowledge creation,collection and updating (KCCU). INT. J. Project Organisation and Management, Vol.1, No.2.

Holm, J. (2001), "Capturing the spirit of knowledge management", paper presented at the American Conference on Information Systems, Boston, MA, August 3-5.

Karami, M. Alvani, S M. Zare, H. Kheirandish,(2015)."Determination of critical success factor of knowledge management implementation, using qualitative and quantitative tools (case study:bahman automobile industry)". Iranian Journal of Management Studies, vol. 8, No 2, pp:181-201.

Kayani, J. Zia, M. Q.(2012). The analysis of knowledge, knowledge management and knowledge management cycles: A Broad Review.International Journal of Academic research in econamic and management sciences, Vol.1,No.6.

Lee, C. and Yang, J. (2000), "Knowledge value chain", The Journal of Management Development, Vol. 19 No. 9, pp. 783-94.

Nonaka I, Takeuchi H. The knowledge-creating company: How Japanese companies create the dynamics of innovation. New York: Oxford University Press; 1995.

Oakland, J, s. (1995) Total Quality Management-Text with Cases (Oxford, Butterworth-Heinemann).

Polanyi, M. (1958), Personal Knowledge, University of Chicago Press, Chicago, Illinois.

Polyani, M. (1966), The Tacit Dimension, Routledge \& Kegan Paul, London.

Ranjan J, \& Bhatnagar V. (2008). "Critical success factors for implementing CRM using data mining". Journal of Knowledge Management Practice, 9(3), 18-25.

Stankosky, M. (2008). Keynote address to ICICKM (International Conference on Intellectual Capital,Knowledge Management and Organisationa I Learning (9-10).

Srikantaih, K.; Koenig, M. (2001). "Knowledge Management: For the Information Professional" Medford, N.J. American Society for Information Science.

Wiig, K. M. (1993), Knowledge Management Foundations, Schema Press, Texas. 
Wong,K Y. (2005),"Critical success factor for implementing knowledge management in small and medium enterprises". Industrial Management and Data Systems,vol.105 less 3 pp.261-279

Wu JH, Wang YM. (2006) Measuring KMS success: a respecification of the Delone and McLean's model. Information and Management; 43(2):728-739.

Wu,W-W. (2011)."Segmenting critical factors for successful knowledge management implementation using the fuzzy DEMATEL method".Applied Soft Computing. 